\title{
EFEK NEFROPROTEKTIF KOMBINASI EKSTRAK DAUN GEDI MERAH DAN DAUN KUMIS KUCING PADA TIKUS INDUKSI ETILEN GLIKOL
}

\author{
Joni Tandi ${ }^{1, *}$, Moh. Roem ${ }^{1}$, Yuliet ${ }^{2}$ \\ ${ }^{1}$ Pogram Studi farmasi, STIFA Pelita Mas Palu, Sulawesi Tengah \\ ${ }^{2}$ Jurusan Farmasi, FMIPA, UNTAD Palu, Sulawesi Tengah \\ *Email : jonitandi757@yahoo.com
}

\begin{abstract}
Nephroprotective compound is a compound that has the ability to protect the kidneys from kidney disorders caused by free radicals. This research aimed to determine the nephroprotective effect of the combination of Abelmoschus manihot leaves and Orthosiphon stamineus leaves extract as well as to know the effective extract dose combinations as nephroprotective. This research applied Group Random Design with 6 treatment groups consists of 5 tested animals. Group I was normal control. Group II was negative control. All extract groups was given 0,75\% of ethylene glycol and 2\% of ammonium chloride. Group III was given $100 \mathrm{mg} / \mathrm{kg}$ BW of Abelmoschus manihot leaves extract and $200 \mathrm{mg} / \mathrm{kg} B W$ of Orthosiphon stamineus leaves extract. Group IV was given $50 \mathrm{mg} / \mathrm{kg}$ BW of Abelmoschus manihot leaves extract and 100 $\mathrm{mg} / \mathrm{kg}$ BW of Orthosiphon stamineus leaves extract. Group $V$ was given $100 \mathrm{mg} / \mathrm{kg} \mathrm{BW}$ of Abelmoschus manihot leaves extract. Group VI was given $200 \mathrm{mg} / \mathrm{kg}$ BW of Orthosiphon stamineus leaves extract. Treatment was given for 14 days and the levels of creatine and urea were measured on day 0, 8 and 15. The results show the nephroprotective effect in all the extract groups, but the most effective one was the group III.
\end{abstract}

Keywords: Nefroprotective, ethylene glycol, Abelmoschus manihot, Orthosiphon stamineus

\begin{abstract}
ABSTRAK
Senyawa yang bersifat nefroprotektif adalah senyawa yang memiliki kemampuan melindungi ginjal dari gangguan ginjal yang disebabkan oleh radikal bebas. Penelitian ini bertujuan untuk mengetahui efek nefroprotektif kombinasi ekstrak daun gedi merah dan daun kumis kucing serta mengetahui kombinasi dosis ekstrak yang efektif sebagai nefroprotektif. Penelitian ini menggunakan Rancangan Acak Kelompok dengan 6 kelompok perlakuan terdiri dari 5 ekor tikus. Kelompok I kontrol normal. Kelompok II kontrol negatif. Semua kelompok ekstrak diberikan etilen glikol 0,75\%, amonium klorida $2 \%$ \& perlakuan ekstrak untuk masing-masing kelompok. Kelompok III (kombinasi 1) diberikan ekstrak daun gedi merah $100 \mathrm{mg} / \mathrm{kg}$ BB dan daun kumis kucing $200 \mathrm{mg} / \mathrm{kg}$ BB. Kelompok IV (kombinasi 2) diberikan ekstrak daun gedi merah $50 \mathrm{mg} / \mathrm{kg}$ BB dan daun kumis kucing $100 \mathrm{mg} / \mathrm{kg}$ BB. Kelompok V diberikan ekstrak daun gedi merah $100 \mathrm{mg} / \mathrm{kg}$ BB. Kelompok VI ekstrak daun kumis kucing $200 \mathrm{mg} / \mathrm{kg} \mathrm{BB}$. Perlakuan diberikan selama 14 hari dan dilakukan pengukuran kadar kreatinin dan ureum pada
\end{abstract}


hari ke-0, 8, dan 15 . Hasil yang diperoleh menunjukkan adanya efek nefroprotektif pada semua kelompok ekstrak, namun yang paling efektif adalah kelompok III.

Kata kunci : Nefroprotektif, etilen glikol, Abelmoschus manihot, Orthosiphon stamineus

\section{PENDAHULUAN}

Kasus penyakit batu saluran kemih di Indonesia banyak dijumpai, menyebabkan tingkat kesakitan yang tinggi, hilangnya jam kerja pada saat beraktivitas dan memerlukan biaya pengobatan yang cukup mahal ${ }^{1}$.

Penyakit ginjal merupakan penyakit yang persentasenya terus meningkat dari tahun ke tahun. Jumlah pasien dalam dunia kesehatan yang menderita penyakit ginjal kronis di Indonesia meningkat dengan sangat cepat. Penyakit ginjal kronis umumnya berlanjut menjadi penyakit ginjal tahap akhir (EndStage Renal Disease (ESRD) atau gagal ginjal total. ESRD (End-Stage Renal Disease) merupakan kondisi ketika kerja ginjal tidak dapat memenuhi kebutuhan harian tubuh dan hemodialisis merupakan salah satu cara pengobatan penyakit tersebut 2,3. Penyakit gagal ginjal kronik meningkat pada tahun 2013 seiring dengan bertambahnya umur, meningkat tajam pada umur 35-44 tahun (0,3\%) diikuti umur 45-54 tahun $(0,4 \%)$ dan umur 55-74 tahun $(0,5 \%)$, tertinggi pada kelompok umur $\geq 75$ tahun $(0,6 \%)$. Wilayah Sulawesi Tengah dari 0,5\% ditahun 2009 meningkat menjadi 0,8\% ditahun $2013^{4}$.

Pemanfaatan tanaman obat dikalangan masyarakat sebagai obat tradisional bukanlah hal yang baru. Masyarakat Indonesia telah mengenal dan menggunakan obat tradisional sejak dulu kala sebagai warisan nenek moyang. Obat tradisional ini, baik berupa jamu maupun tanaman obat masih digunakan hingga saat ini. Karena dilihat dari kelebihan obat tradisional adalah efek sampingnya relatif rendah serta pada satu tanaman memiliki lebih dari satu efek farmakologi serta lebih sesuai untuk penyakit-penyakit metabolik dan degeneratif ${ }^{5}$.
Daun gedi merah (Abelmoschus manihot L.) merupakan obat tradisional yang digunakan untuk membantu penyembuhan pengobatan, salah satunya mengurangi dan melindungi kerusakan ginjal 6 . Penelitian yang menyatakan bahwa ekstrak etanol daun gedi merah (Abelmoschus manihot L.) dosis $100 \mathrm{mg} / \mathrm{kg}$ BB merupakan dosis yang efektif untuk menghambat kenaikan kadar kreatinin dan ureum akibat induksi etilen glikol. Selain itu, Tanaman gedi merah memiliki kemampuan antinosiseptif, kardioprotektif, hepatoprotektif, dan efek protektif terhadap gastrimukosal ${ }^{7}$.

Daun kumis kucing (Orthosiphon stamieus Benth) merupakan tanaman yang digunakan sebagai pengobatan, termasuk nefroprotektif untuk menurunkan kadar kreatinin dan ureum serta meningkatkan GFR (Glomerulus Filtration Rate). Ekstrak daun kumis kucing (Orthosiphon stamineus B.) dosis $200 \mathrm{mg} / \mathrm{kg}$ BB dosis yang efektif untuk menurunkan kadar kreatinin dan ureum akibat induksi gentamisin. Kandungan tanaman kumis kucing antara lain minyak atsiri, flavonoid, orthosiphon glikosida, saponin, garam kalium serta myoinositol ${ }^{8}$.

Penelitian ini bertujuan untuk mengetahui efek nefroprotektif kombinasi ekstrak daun gedi merah dan daun kumis kucing serta mengetahui kombinasi dosis yang efektif sebagai nefroprotektif.

\section{METODE PENELITIAN}


tetes, rak tabung, rotavapor, sendok tanduk, sentrifuge, sonde oral, spoit $1 \mathrm{ml}, 3 \mathrm{ml}$, dan 5 $\mathrm{ml}$, stopwatch, tabung darah, timbangan analitik, timbangan kasar, tabung darah, waterbath.

\section{Bahan}

Alumunium foil, alkohol $70 \%$, amonium klorida, amonium klorida, aquadest, asam klorida pekat, betadine, etanol $96 \%$, etilen glikol, $\mathrm{FeCl}_{3}$, kapas, kertas saring, kit kreatinin, kit ureum, magnesium, metanol, $\mathrm{Na}$ $\mathrm{CMC}$, pereaksi dragendorf, serbuk simplisia daun gedi merah dan daun kumis kucing.

\section{Pengambilan dan Pengolahan Bahan Uji}

Daun gedi merah diambil di kota Poso pada pagi hari, daun yang diambil adalah daun yang baik yang masih tampak segar dan hijau (dihitung 5 lembar dari pucuk) dan dipetik langsung dengan tangan, sedangkan serbuk simplisia daun kumis kucing diperoleh dari UPT Materia Medica, Kota Batu.

\section{Pembuatan Ekstrak Daun Gedi Merah dan Daun Kumis Kucing}

Serbuk simplisia daun gedi merah dengan berat 350 gram dan daun kumis kucing 450 gram masing-masing diekstraksi dengan metode remaserasi selama 3 hari menggunakan larutan penyari etanol $96 \%$ sebanyak 2,7 liter (diaduk sesekali). Kemudian dirotavapor dengan suhu $60^{\circ} \mathrm{C}$, dipekatkan di atas penangas air dengan suhu $40^{\circ} \mathrm{C}$ sehingga diperoleh ekstrak kental.

\section{Pembuatan Suspensi Sampel Uji}

Suspensi bahan uji yakni kombinasi ekstrak etanol daun gedi merah (Abelmoscus manihot L.) dan daun kumis kucing (Orthosiphon stamineus B.) dengan masingmasing sebanyak $0,1 \mathrm{~g}+0,2 \mathrm{~g}$ (untuk dosis $100 \mathrm{mg} / \mathrm{kg} \mathrm{BB}+$ dosis $200 \mathrm{mg} / \mathrm{kg} \mathrm{BB}$ ), 0,05 $\mathrm{g}+0,1 \mathrm{~g}$ (untuk dosis $50 \mathrm{mg} / \mathrm{kg} \mathrm{BB}+$ dosis $100 \mathrm{mg} / \mathrm{kg} \mathrm{BB}$ ). Masing-masing dimasukkan dalam suspensi $\mathrm{Na}$ CMC 0,5\% sedikit demi sedikit, dicampur hingga homogen dan ditambahkan suspensi $\mathrm{Na}$ CMC 0,5\% hingga $5 \mathrm{ml}$.

\section{Perlakuan Pada Hewan Uji}

Hewan uji diadaptasikan selama 2 minggu sebanyak 30 ekor, ditimbang, diukur kadar kreatinin dan ureum awal (baseline) kemudian dibagi menjadi 6 kelompok, masing-masing kelompok terdiri atas 5 ekor tikus. Kelompok normal hewan uji diberikan suspensi Na CMC 0,5\%, kelompok (-) hewan uji diinduksi etilen glikol 0,75\%, amonium klorida $2 \%$, dan Na CMC 0,5\% secara oral, kelompok uji yang terdiri dari kelompok 3, 4, 5 dan 6 diinduksi dengan etilen glikol $0,75 \%$ dan amonium klorida $2 \%$ secara oral dan diberikan K1 (kombinasi 1; ekstrak daun gedi merah dosis $100 \mathrm{mg} / \mathrm{kg} \mathrm{BB}$ dan daun kumis kucing dosis $200 \mathrm{mg} / \mathrm{kg} \mathrm{BB}$ ), K2 (kombinasi 2 ; ekstrak daun gedi merah dosis $50 \mathrm{mg} / \mathrm{kg}$ BB dan daun kumis kucing dosis $100 \mathrm{mg} / \mathrm{kg} \mathrm{BB}$ ), T1 (Tunggal 1) ekstrak daun gedi merah dosis $100 \mathrm{mg} / \mathrm{kg} \mathrm{BB}$ dan T2 (Tunggal 2) ekstrak daun kumis kucing dosis $200 \mathrm{mg} / \mathrm{kg}$ BB. Perlakuan diberikan selama 14 hari berturut-turut. Tikus dipuasakan selama 16 jam sebelum pengambilan darah yang dilakukan pada hari ke-0 (pra perlakuan), hari ke-8 dan hari ke-15 (post perlakuan).

\section{Analisis Data}

Data hasil pengukuran kadar kreatinin dihitung, dianalisis secara statistik dengan uji One Way Anova pada taraf kepercayaan 95\%, dilanjutkan dengan uji lanjut post hoc Duncan untuk menentukan kombinasi dosis ekstrak yang efektif. Pengolahan data dilakukan dengan menggunakan program software SPSS 21. 


\section{HASIL PENELITIAN}

Tabel 1. Uji Penapisan Fitokimia Ekstrak Etanol Daun Gedi Merah dan Kumis Kucing

\begin{tabular}{ccccc}
\hline \multirow{2}{*}{ No } & \multirow{2}{*}{ Senyawa bioaktif } & \multirow{2}{*}{ Pereaksi } & \multicolumn{2}{c}{ Hasil } \\
\cline { 3 - 5 } & Alkaloid & Dragendorf & + & KK \\
\hline 1 & Flavonoid & Magnesium dan $\mathrm{HCl}$ & + & + \\
2 & Saponin & Tes pembentukkan busa & + & + \\
3 & Tanin & $\mathrm{FeCl}_{3} 1 \%$ & + & + \\
4 & Polifenol & $\mathrm{FeCl}_{3} 5 \%$ & + & + \\
\hline
\end{tabular}

Keterangan:

(+) : Menunjukkan adanya kandungan alkaloid, flavonoid, saponin, tanin, dan polifenol. GM : Gedi Merah

KK : Kumis Kucing

Tabel 2. Hasil pengukuran kadar kreatinin (mg/dL) sebelum perlakuan (baseline) dan setelah perlakuan disajikan dalam bentuk rerata \pm SD

\begin{tabular}{cccc}
\hline \multirow{2}{*}{ Perlakuan } & \multicolumn{3}{c}{ Hasil rerata \pm SD Kadar Kreatinin } \\
\cline { 2 - 4 } & Hari-0 & Hari-8 & Hari-15 \\
\hline Kontrol Normal & $0,82 \pm 0,06$ & $0,92 \pm 0,05^{\mathrm{b}}$ & $0,90 \pm 0,25^{\mathrm{a}}$ \\
Kontrol Negatif & $0,89 \pm 0,11^{\mathrm{ab}}$ & $1,83 \pm 0,34^{\mathrm{c}}$ & $2,76 \pm 0,89^{\mathrm{b}}$ \\
K1 & $0,91 \pm 0,06^{\mathrm{ab}}$ & $0,63 \pm 0,06^{\mathrm{a}}$ & $0,76 \pm 0,10^{\mathrm{a}}$ \\
K2 & $0,89 \pm 0,12^{\mathrm{ab}}$ & $0,72 \pm 0,07^{\mathrm{ab}}$ & $0,78 \pm 0,09^{\mathrm{a}}$ \\
T1 & $0,82 \pm 0,09^{\mathrm{a}}$ & $0,78 \pm 0,11^{\mathrm{ab}}$ & $0,76 \pm 0,13^{\mathrm{a}}$ \\
T2 & $1,00 \pm 0,13^{\mathrm{b}}$ & $0,79 \pm 0,07^{\mathrm{ab}}$ & $0,72 \pm 0,17^{\mathrm{a}}$ \\
\hline
\end{tabular}

Keterangan:

$\mathrm{K} 1=$ Kombinasi $1 \quad \mathrm{~K} 2=$ Kombinasi 2

$\mathrm{T} 1=$ Ekstrak tunggal daun gedi merah $\quad$ T2 = Ekstrak tunggal daun kumis kucing Abjad yang berbeda menunjukkan perbedaan yang signifikan Abjad yang sama menunjukkan perbedaan yang tidak signifikan

Tabel 3. Hasil pengukuran kadar ureum (mg/dL) sebelum perlakuan (baseline) dan setelah perlakuan disajikan dalam bentuk rerata \pm SD

\begin{tabular}{cccc}
\hline \multirow{2}{*}{ Perlakuan } & \multicolumn{3}{c}{ Hasil rerata \pm SD Kadar Ureum } \\
\cline { 2 - 4 } & Hari-0 & Hari-8 & Hari-15 \\
\hline Kontrol Normal & $33,2 \pm 3,15^{\mathrm{ab}}$ & $44,2 \pm 2,36^{\mathrm{a}}$ & $43,0 \pm 12,6^{\mathrm{a}}$ \\
Kontrol Negatif & $33,5 \pm 5,47^{\mathrm{abc}}$ & $126,1 \pm 21,2^{\mathrm{b}}$ & $204,9 \pm 41,6^{\mathrm{b}}$ \\
K1 & $39,3 \pm 2,75^{\mathrm{bc}}$ & $38,6 \pm 1,52^{\mathrm{a}}$ & $38,0 \pm 6,12^{\mathrm{a}}$ \\
K2 & $40,4 \pm 8,01^{\mathrm{c}}$ & $39,0 \pm 5,23^{\mathrm{a}}$ & $38,4 \pm 6,16^{\mathrm{a}}$ \\
T1 & $30,9 \pm 3,43^{\mathrm{a}}$ & $39,1 \pm 8,69^{\mathrm{a}}$ & $37,5 \pm 3,40^{\mathrm{a}}$ \\
T2 & $33,2 \pm 3,63^{\mathrm{ab}}$ & $35,7 \pm 4,27^{\mathrm{a}}$ & $52,1 \pm 14,7^{\mathrm{a}}$ \\
\hline
\end{tabular}




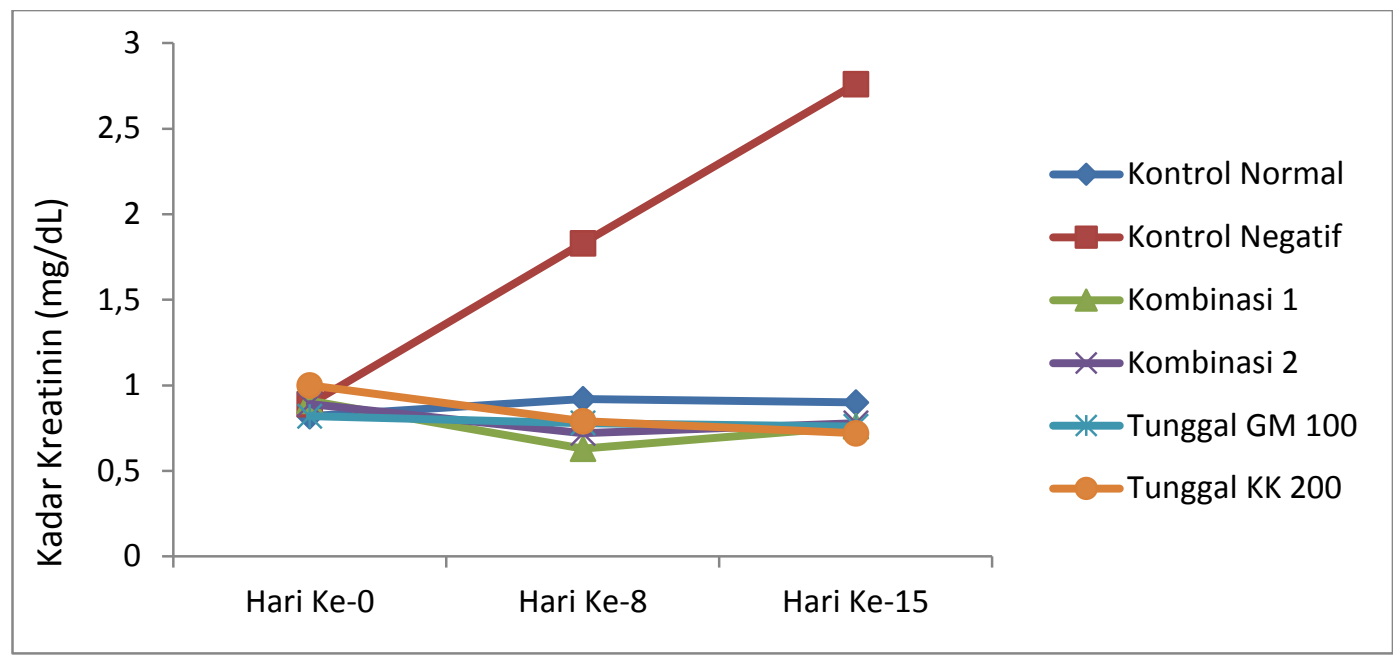

Gambar 1. Profil Kadar Kreatinin Serum Tikus Putih

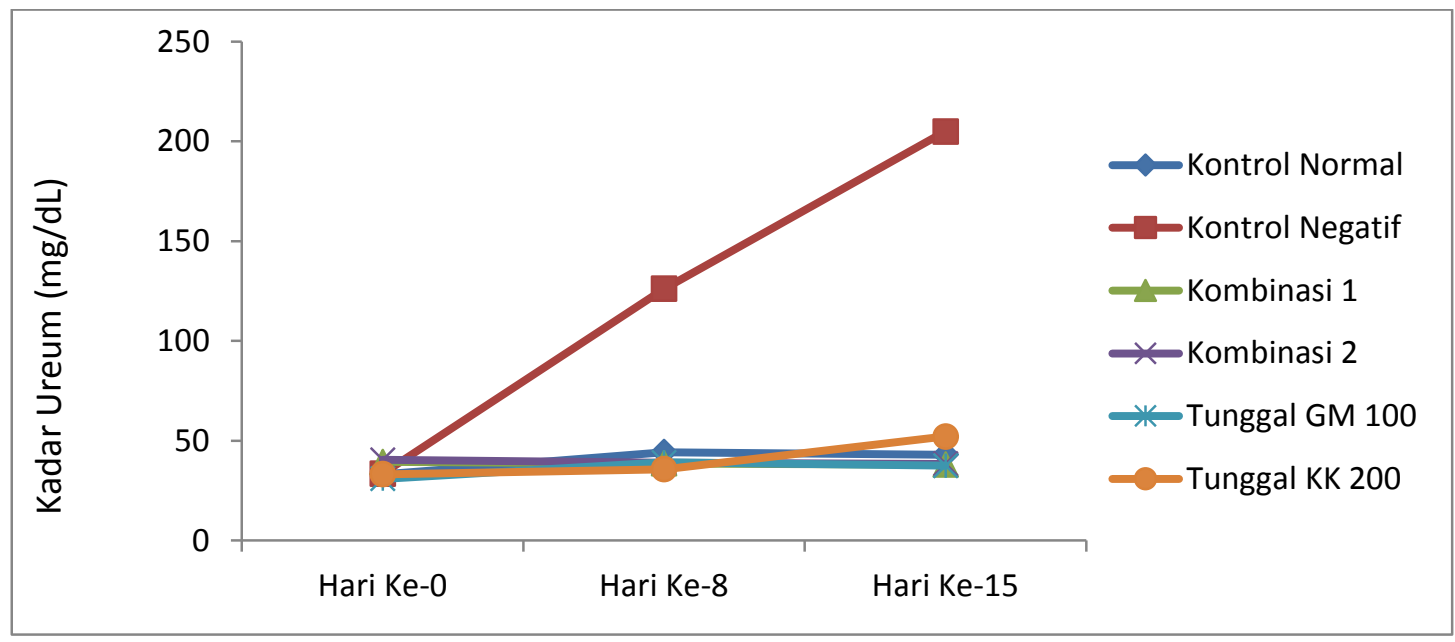

Gambar 2. Profil Kadar Ureum Serum Tikus Putih

\section{PEMBAHASAN}

Penelitian ini dilakukan untuk mengetahui efek nefroprotektif kombinasi ekstrak daun gedi merah (Abelmoschus manihot L.) dan daun kumis kucing (Orthosiphon stamineus B.) dengan parameter yang diambil adalah kadar kreatinin dan ureum pada tikus putih jantan (Rattus norvegicus) yang diinduksi etilen glikol. Bahan uji yang digunakan adalah daun gedi merah (Abelmoschus manihot (L.)
Medik) dan daun kumis kucing (Orthosiphon stamineus B.). Tanaman yang digunakan determinasi dengan tujuan memastikan bahwa tanaman yang digunakan tersebut benar spesies Abelmoschus manihot L. dari suku Malvaceae dan daun kumis kucing yang digunakan tersebut benar spesies Orthosiphon stamineus B. dari suku Labiatae.

Metode ekstraksi yang digunakan dalam 
penelitian ini yaitu metode maserasi. Alasan penggunaan metode ekstraksi ini karena tekstur bahan uji berupa daun yang lunak dan mudah mengembang dalam cairan penyari. Cairan penyari yang digunakan dalam proses maserasi ini adalah etanol 96\%. Etanol digunakan sebagai cairan penyari karena tidak beracun, netral, absorbsinya baik, etanol dapat bercampur dengan air dalam segala perbandingan dan zat pengganggu yang larut terbatas. Etanol juga merupakan pelarut yang universal yang dapat menarik senyawa bersifat polar, semi polar dan non polar.

Penginduksi yang digunakan adalah etilen glikol dan ammonium klorida. Etilen glikol dimetabolisme dalam hati menghasilkan senyawa metabolit oksalat, sehingga menghasilkan hiperoksaluria yang dapat berikatan dengan kalsium dalam darah membentuk kalsium oksalat yang terdapat dalam ginjal. Amonium klorida berfungsi sebagai katalisator untuk mempercepat pembentukan batu ginjal kalsium oksalat.

Penelitian yang menyatakan bahwa induksi kombinasi etilen glikol 0,75\% dan amonium klorida $2 \%$ pada tikus putih selama 10 hari dapat menyebabkan terjadinya urolithiasis. Hal ini disebabkan metabolisme akhir etilen glikol adalah senyawa oksalat yang kemudian mengendap bersama kalsium membentuk kristal kalsium oksalat $(\mathrm{CaO})^{9}$.

Hasil uji lanjut Duncan terhadap kadar kreatinin daun ureum kombinasi 1 (ekstrak daun gedi merah $100 \mathrm{mg} / \mathrm{kg} \mathrm{BB}$ dan ekstrak daun kumis kucing $200 \mathrm{mg} / \mathrm{kg} \mathrm{BB}$ ) dan kombinasi 2 (ekstrak daun gedi merah 50 $\mathrm{mg} / \mathrm{kg}$ BB dan ekstrak daun kumis kucing $100 \mathrm{mg} / \mathrm{kg}$ BB) pada hari ke-8 menunjukkan perbedaan signifikan dengan kontrol negatif. Hal ini menunjukkan adanya efek nefroprotektif yang ditunjukkan oleh kombinasi 1 dan kombinasi 2 dimana kadar kreatinin dan ureum lebih rendah dibandingkan kontrol negatif yang hanya diberikan Na CMC.

Pemberian perlakuan sesuai kelompok dilakukan selama 14 hari dan dilakukan pengukuran kadar kreatinin dan ureum pada hari ke-15 dengan tujuan untuk melihat perlakuan jangka panjang efek nefroprotektif kombinasi ekstrak serta mengetahui nilai perbedaan signifikan antar kelompok perlakuan, dimana dilakukan uji analisis one way anova terhadap kadar kreatinin dan ureum pada hari ke-15 menunjukkan ada perbedaan antara perlakuan dengan nilai $\mathrm{p}<0,05(\mathrm{p}=0,005)$ sehingga dilakukan uji lanjut Duncan.

Hasil uji lanjut Duncan terhadap kadar kreatinin ureum kombinasi 1 (ekstrak daun gedi merah $100 \mathrm{mg} / \mathrm{kg}$ BB dan ekstrak daun kumis kucing $200 \mathrm{mg} / \mathrm{kg} \mathrm{BB}$ ) kombinasi 2 (ekstrak daun gedi merah $50 \mathrm{mg} / \mathrm{kg}$ BB dan ekstrak daun kumis kucing $100 \mathrm{mg} / \mathrm{kg} \mathrm{BB}$ ) pada hari ke-15 menunjukkan perbedaan signifikan dengan kontrol negatif. Hal ini menunjukkan adanya efek nefroprotektif yang ditunjukkan oleh kombinasi 1 dan kombinasi 2 dimana kadar kreatinin dan ureum lebih rendah dibandingkan kontrol negatif yang hanya diberikan $\mathrm{Na} \mathrm{CMC}$ $0,5 \%$. Kombinasi 1 dan kombinasi 2 mengandung kombinasi ekstrak dengan dosis yang sesuai sehingga senyawa bioaktif yang terdapat dalam ekstrak dapat terabsorbsi dan terpenetrasi dengan sempurna serta berikatan dengan reseptor sehingga memberikan efek nefroprotektif dengan menghambat peningkatan kadar kreatinin setelah perlakuan jangka pendek(setelah 7 hari) maupun jangka panjang (setelah 14 hari).

Berdasarkan uji Duncan pada hari ke15 , Kombinasi dosis yang efektif sebagai nefroprotektif adalah kombinasi 1 yakni ekstrak daun gedi merah dosis $50 \mathrm{mg} / \mathrm{kg}$ BB dan daun kumis kucing $100 \mathrm{mg} / \mathrm{kg}$ BB yang mendekati kontrol normal. Hal ini disebabkan pada kombinasi 1 mengandung flavonoid dan fenol dengan aktifvitas antioksidan tinggi, sehingga dapat 
terabsorbsi dengan baik dan terpenetrasi dengan sempurna di dalam tubuh untuk mencapai reseptornya. Kandungan senyawa flavonoid yang terdapat dalam kedua tanaman dapat memberikan efek yang potensial, yaitu dapat bekerja sebagai antioksidan dan diuretikum sehingga meningkatkan laju filtrasi glomerulus ${ }^{10}$. Peningkatan laju filtrasi glomerulus menyebabkan zat nefrotoksik yang masuk ke dalam ginjal akan dikeluarkan secara cepat akibat aktivitas urinisasi yang meningkat. Pengeluaran tersebut dapat meminimalisir terjadinya akumulasi kalsium oksalat yang diakibatkan induksi etilen glikol.

\section{Kesimpulan}

Berdasarkan hasil penelitian, maka dapat disimpulkan bahwa:

1. Kombinasi ekstrak daun gedi merah (Abelmoschus manihot L.) dan daun kumis kucing (Orthosiphon stamineus B.) dapat menghambat peningkatan kadar ureum dan kreatinin tikus putih jantan (Rattus norvegicus) yang diinduksi etilen glikol.

2. Kombinasi ekstrak daun gedi merah (Abelmoschus manihot L.) dengan dosis $50 \mathrm{mg} / \mathrm{kg}$ BB dan daun kumis kucing (Orthosiphon stamineus B.) dengan dosis $100 \mathrm{mg} / \mathrm{kg} \quad \mathrm{BB}$ efektif dalam menghambat peningkatan kadar ureum dan kreatinin tikus putih jantan (Rattus norvegicus) yang diinduksi etilen glikol.

\section{Saran}

Berdasarkan hasil penelitian maka disarankan untuk penelitian selanjutnya sebagai berikut :

1. Perlu dilakukan penelitian lebih lanjut dengan menggunakan kombinasi ekstrak dalam bentuk terpurifikasi ekstrak daun gedi merah (Abelmoschus manihot L.) dan daun kumis kucing (Orthosiphon stamineus B.)
2. Perlu diadakan penelitian mengenai gambaran hispatologi terhadap ginjal yang telah mengalami kerusakan untuk melihat aktivitas antioksidan ekstrak dalam meregenerasi sel-sel ginjal.

\section{Daftar Pustaka}

1. Ashadi T. 1998. Manfaat Diagnosa Radiografi pada Batu Saluran Kemih. Medika 24 (8) : 544-549

2. Noer. 1992. Evaluasi Fungsi Ginjal Secara Laboratorik. Surabaya: Unair. (Hal 7-8)

3. Strukle PD. 1976. Kidney, External Salt Extretion and Urine. In: Avian Physiologi. Edisi ke-3 New York. Heldelber, Springer. Verlag. Hal 43-50

4. RISKESDA (Riset Kesehatan Dasar). 2013. Info aktual : Gangguan ginjal 2013 Sulawesi Tengah.

5. Larasati, 2012. Efek Penurunan Kadar Glukosa Darah Kombinasi Ekstrak Etanol Daun Alpukat (Persea Americana Hill) dan Buah Oyong (Luffa acutangula (L.) Roxb) Pada Mencit Putih Jantan Yang Dibebani Glukosa.Universitas Indonesia. Skripsi

6. Shao-Yu Z., Nai-Ning S., Wen-Yuan G., Wei J., Hong-Quan D. and Pei-Gen X., 2006, Progress in the treatment of chronic glomerulonephritis with traditional Chinese medicine, Asian Journal of Pharmacodynamic and Pharmacokinetics 6 (4): 317 - 325

7. Gosal, D. 2014. Pengaruh Eksrak Etanol Daun Gedi Merah (Abelmoschus manihot (L.) Medik) Terhadap Gambaran Kreatinin Tikus Putih Jantan (Rattus norvegicus) Yang Diinduksi Etilen Glikol. Skripsi. Sekolah Tinggi Ilmu Farmasi. Palu. Hal : 45

8. Cyntia, V. 2012. Pengaruh Pemberian Ekstrak Daun Kumis Kucing (Orthosiphon aristatus) Terhadap Penurunan Kadar Glukosa Darah Tikus Wistar Yang Diinduksi Aloksan. Skripsi. Universitas Diponegoro. Hal : 9 
9. Hardyanto, J. 2013. Efek Perasan Daun dan Tangkai Semanggi Air (Marsilea Crenata) Terhadap Penurunan Kadar Tumor Necrosis Factor Alpha (TNF- $\alpha$ ) Dan Interleukin 1 Beta (IL-1 $\beta$ ) Pada Tikus Putih (Rattus Norvegicus) Urolithiasis.Jurnal Ilmiah. Vol. $1: 3$
10. Adi Arianto Wibowo. 2012. Pengaruh Ekstrak Daun Kemangi (Ocimum sanctum) Terhadap Penurunan Kadar Kreatinin Dalam Darah Tikus Putih (Rattus norvegicus) yang Diinduksi Parasetamol. Fakultas Kedokteran Universitas Sebelas Maret. Surakarta. Hal 22-30 